\title{
A reflection on Priscilla Queen of the Desert
}

"Oh I, I love the nightlife

I got to boogie

On the disco 'round, oh yea"

Alicia Bridges (1978)

In 1994 I watched the film, The Adventures of Priscilla, Queen of the Desert with my best friend in Murupara, a small, predominantly Māori town in the Bay of Plenty. The movie was intense. It was colourful. It was inspiring. This movie was my first experience seeing anything to do with gay, transgender, or drag. Murupara was a town filled with rough talking, hardworking people, with hearts of gold. It was a tight-knit community.

I was 14 when I watched the Priscilla film; I was a fourth former at Rangitahi College. Looking back, Rangitahi College was literally a school of hard knocks. You had to be tough at times. My friend and I were often teased and called "faggots". In fact, there were a group of so-called faggots at Rangitahi College; we hung out together and protected one another. We developed acid-tongues and could throw out a soul-destroying comment at will! This was our defence mechanism. Our school of hard knocks meant that we - and everyone else too - had to be strong; we needed a certain amount of amour to protect ourselves with. 
Another part of the defence mechanism at school was popularity with the girls. If you were popular with the girls especially the important girls - you had their favour and the somewhat reserved favour of their boyfriends. We were topnotch strategists! Many life-long friends, of course, developed from these relationships; but at that time, it was a matter of survival.

My memories of the movie are still vivid and bright even though I have not seen the film for more than a decade. The film was inspirational to us. Though we had not seen or heard of drag queens before, the concepts of men enjoying dressing up seemed quite natural to us.

On Friday 8 June 2018 I watched Priscilla Queen of the Desert, the musical, at Capitol Theatre in Sydney. The musical in Sydney stars Euan Doidge of Ngāti Whakaue descent, who plays Felicia. According to Māori Television (2018):

A young Māori actor has taken on one of the leading roles in Priscilla Queen of the Desert: The Musical, currently playing at Sydney's Capitol Theatre. 24-yearold Euan Doidge of Ngāti Whakaue has spent most of his life living in Australia and trained at MJ Dance studio in Gambier, and has landed other big musical roles including Legally Blonde and Grease.

Speaking of his time playing Felicia he explains, "I've had a lot of time to delve into this character and watching the film a few times has really kind of helped me, but I've had great guidance from our creative team here in Australia, and I honestly do get to have just so much fun on that stage."

Doidge comes from a musical background and had 30 of his family members fly over from New Zealand to Australia to watch him in the Priscilla musical last week.

"I was beside myself nervous, you can ask anyone in the cast, because a lot of them hadn't seen me do a show before and so for me that's a very big thing and I am a part of their lives so much even though I don't get to see them as often as I'd like to, knowing that they want to fly all this way to watch a relative do what they love to do is 
so special and it honestly meant the world to me" says Doidge (Māori Television, 2018, n.p.)

Image 1: Euan Doidge in his dressing room for Priscilla Queen of the Desert: The musical

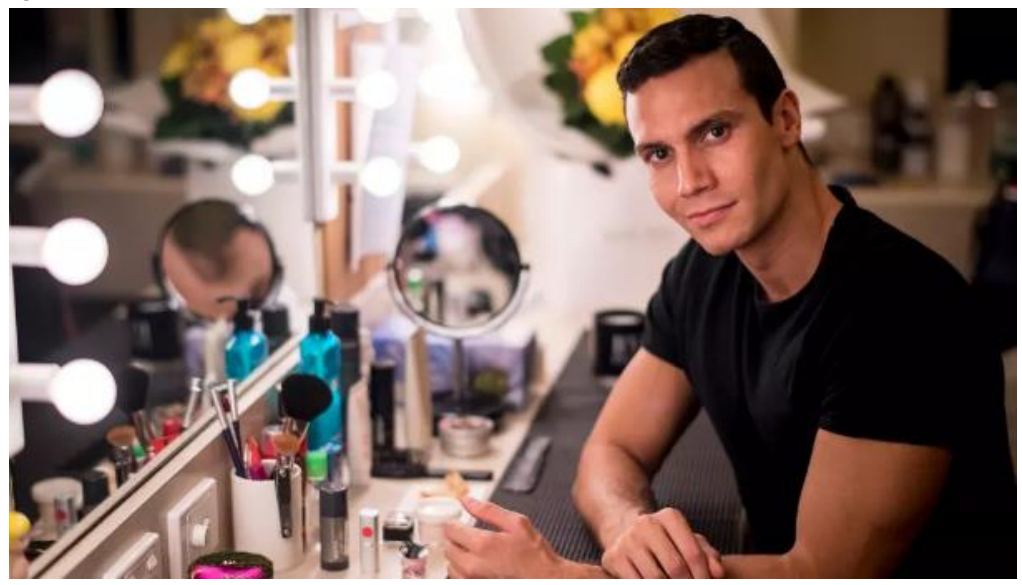

(Cooper, 2018, n.p.). ${ }^{1}$

\section{Ko Felicia toku ingoa}

Sparkling tinsels and rhinestones adorn

Scantily-clad physiques

Camp, cutting comments and

Punchlines slice deep

The audiences erupts into laughter

Disco music abounds

Seat-bound crowds clap and bounce

Ushers ask people to remain seated

During the show, despite the allure

Of the music and the trippy lights

Euan Doidge takes the stage

As Felicia, the hyper-camp

Dazzling, acid-tongued 
Sometimes obnoxious

But well-meaning

Flailing limbed

Sequin encrusted

Seductress of the stage

With big dreams

And an even bigger heart

Twirling and twerking

High-kicking her way

Into our affections

A character adored

Ngāti Whakaue is in the house

Taking Sydney by storm

I live with a drag queen. I am friends with drag queens. While I, myself, am not a drag queen, I greatly appreciate the counter-hegemonic and counter-heteronormative nuances of drag culture. Priscilla - both the film and the musical - are iconic to gay culture. The underlying message in both is that everyone needs and deserves love and respect, regardless of how colourful they are. 


\section{References}

Bridges, A. (1978). I love the nightlife. Alicia Bridges: I love the nightlife. London, United Kingdom: Polydor.

Cooper, N. (2018, February 9). Euan Doidge: The humble star stealing hearts in Priscilla Queen of the Desert. Retrieved from: https://www.smh.com.au/entertainment/musicals/euan-doidgethe-humble-star-stealing-hearts-in-priscilla-queen-of-the-desert20180209-h0vu6g.html

Māori Television (2018). Māori Television (2018). Māori actor in leading role of Priscilla Queen of the Desert musical. Retrieved from: https://www.maoritelevision.com/news/national/maori-actorleading-role-priscilla-queen-desert-musical 